Dhaka Univ. J. Biol. Sci. 24(2): 153-159, 2015 (July)

\title{
EFFECTS OF FEEDS ON GROWTH PERFORMANCE AND NUTRITIONAL COMPOSITION OF CIRRHINUS MRIGALA FINGERLINGS
}

\author{
Polash Chandra Dash, Nahid Sultana ${ }^{* 1}$, Khandker Nesar Ahmed ${ }^{1}$, \\ Mahmuda Begum ${ }^{1}$, Shankar Chandra Mandal and Anwar Hossain \\ Department of Fisheries, University of Dhaka, Dhaka-1000, Bangladesh
}

Key words: Cirrhinus mrigala, Growth performance, FCR, Nutritional composition

\begin{abstract}
Effects of four different feeds on growth and nutrient composition of mrigal fingerlings (Cirrhinus mrigala) were evaluated. After 30 days of rearing growth parameters and quality of fish flesh were examined. During the rearing period, the change in growth and feed utilization by the mrigal fed with feeds have been assessed as condition factor (K), average daily gain (ADG), specific growth rate (SGR) and feed conversion ratio (FCR).The highest FCR (6.23 \pm 0.59$)$ was found in the treatment 4 while the lowest $(3.08 \pm 0.10)$ in the treatment 1 . The condition factor was highest $(0.89 \pm 0.01)$ in treatment 1 while the lowest $(0.81 \pm 0.05)$ in the treatment 4 . After 30 days of rearing, moisture content of mrigal in different treatments was $77.2,78.41,76.99$ and $77.86 \%$ in treatments $1,2,3$ and 4 , respectively. Protein was $17.15,15.89,16.90$ and $14.76 \%$ in treatments $1,2,3$ and 4, respectively. Lipid was $2.07,2.22,2.25$ and $2.85 \%$ and ash content was 3.58 , $3.48,3.88$ and $4.53 \%$ in four $(1,2,3$ and 4$)$ treatments, respectively.
\end{abstract}

\section{Introduction}

Poor people of Bangladesh have been suffering from malnutrition due to lack of proper protein. Fish and fisheries sector can solve this problem partially by increasing fish production through modern and scientific fish culture and management practice. The growth and biomass of fish in intensive and semi-intensive culture system depends on various factors notably feeding regimes. Fish growth at different stages is largely governed by the kind of feed, feeding frequency, feed intake and its ability to absorb the nutrients. Among these, kind of feed is an important factor for the survival and growth of fish at the early stage ${ }^{(1,2)}$.

Protein is the main constituent of the fish body needed for optimum growth. Protein is the most expensive macronutrient in fish $\operatorname{diet}^{(3)}$. So, the amount of protein in the diet should be just enough for fish growth where the excess protein in fish diets may be wasteful and cause diets to be unnecessarily expensive. The level of dietary protein is of fundamental importance, because it significantly influences growth, survival and yield of

${ }^{*}$ Author for correspondence: <nahidsultana0@gmail.com>. ${ }^{1 Z}$ Zoology Section, Bangladesh Council of Scientific and Industrial Research (BCSIR), Dhaka, Bangladesh. 
fish. Therefore, considerable research effort is needed to determine the quantity and quality of dietary protein necessary to achieve optimum growth performance of fish. The present study was aimed at assessing the analysis of growth performance and nutritional composition of Cirrhinus mrigala by feeding different supplementary feeds.

\section{Materials and Methods}

Fingerlings of Cirrhinus mrigala were collected from BFRI (Bangladesh Fisheries Research Institute) at Mymensingh and carried in polythene bags with proper oxygen and water. The experiment was carried out in the laboratory at Zoology Section, Biological Research Division, Bangladesh Council of Scientific and Industrial Research (BCSIR), Dhaka.

Four artificial fish feeds were used for mrigal fingerlings rearing under laboratory condition. Physio-chemical and growth parameters were recorded. Four treatments were conducted in triplicates. Feed-1 was supplied in treatment $T_{1}$, feed-2 in treatment $T_{2}$, feed-3 in treatment $T_{3}$ and feed- 4 was supplied in treatment $T_{4}$. In total 30 fingerlings were stocked in each of the aquariums. Fingerlings brought from BFRI were acclimatized for sometimes in clean water. Then fingerlings were released slowly in aquarium water and at the same time oxygen was supplied with the help of aerator. No feed was given on first day. Feed was supplied regularly on the basis of their body weight $(10 \%$ of their body weight). Four types of feed were used in the experiment as described in Table 1.

Table 1. Types and composition of feeds.

\begin{tabular}{ll}
\hline $\begin{array}{l}\text { Feed } \\
\text { number }\end{array}$ & Composition \\
\hline Feed-1 & $\begin{array}{l}\text { BCSIR feed (Mustard oil cake, soyabean meal, rice bran, vitamin and mineral } \\
\text { mixture) }\end{array}$ \\
Feed-2 & $\begin{array}{l}\text { BCSIR feed (Fish meal, soyabean meal, rice bran, vitamin and mineral mixture) } \\
\text { Feed-3 }\end{array}$ \\
Feed-4 & \begin{tabular}{l} 
Commercial fish feed (mega feed) \\
\hline
\end{tabular}
\end{tabular}

Temperature, dissolved oxygen, light intensity, $\mathrm{pH}$ and ammonia were determined in the experiment.

Fish sampling was done weekly and continued for four weeks. Prior to weighing fish were caught with a fine mesh scoop net and their individual length and weight were recorded with a measuring scale and a weighting balance. After 30 days of rearing, the final measurements of length $(\mathrm{cm})$ and weight $(\mathrm{g})$ of the fishes were carefully recorded. 
Condition factor was calculated by the formula of $\mathrm{K}=\left(\mathrm{W} / \mathrm{L}^{3}\right) \times 100$, where, $\mathrm{K}=$ condition factor, $\mathrm{W}=$ body weight $(\mathrm{gm})$ and $\mathrm{L}=$ body length $(\mathrm{cm})$.

Average daily gain was determined by the formula of $A D G=($ Mean final fish weight - mean initial weight)/time $\left(T_{2}-T_{1}\right)$; where $T_{1}=$ initial time, $T_{2}=$ final time. Specific growth rate was calculated as the percentage increase in weight per animal per day as SGR $=100$ $\times\left(\mathrm{LnW}_{\mathrm{t}}-\mathrm{LnW}_{1}\right) / \mathrm{T}-\mathrm{t}$; where, $\mathrm{LnW}_{\mathrm{t}}=$ natural log of weight at time $\mathrm{T}, \mathrm{LnW}_{1}=$ natural log of initial weight, $\mathrm{T}=$ time $\mathrm{T}, \mathrm{t}=$ initial time. $\mathrm{FCR}$ was calculated formula of $\mathrm{FCR}=($ Feed consumed by the fish $(\mathrm{g}) /$ live weight of the fish $(\mathrm{g})$. All the parameters were determined according to Marimuthu et al.(4).

The proximate composition (moisture, protein, fat and ash content) of the sample was determined. Moisture content was determined by oven drying method ${ }^{(5)}$. Crude protein content was determined by using Kjeldahl machine. Protein conversion factor (6.25) was used in converting nitrogen to crude protein. Protein was determined by using 3 steps.

Crude lipid was determined by sing the Soxlet system, (Model Tecator Sox-tact system HT 1043-001 Manual 1983) for extracting lipids of samples. Ash content was determined by gravimetric method by ignition of samples in a muffle-furnace at $550^{\circ} \mathrm{C}$ for 16 hours.

Data were analyzed using one-way ANOVA using SPSS version 11.5. Multivariate analysis was also performed. Tukey's post hoc test was performed with the level of significance at $\mathrm{p}<0.05$.

\section{Results and Discussion}

During this study the growth performance of mrigal fingerlings varied in different artificial fish feed. The growth performance parameters were Condition Factor (K), average daily gain (ADG), specific growth rate (SGR) and feed conversion ratio (FCR). No significant difference in condition factor was found within and between treatments $(\mathrm{p}<0.05)$ (Table 2).

Table 2. Condition factor $(K)$ at 30 days rearing period (Mean \pm SEM).

\begin{tabular}{lcccc}
\hline Treatment & \multicolumn{4}{c}{ Condition factor $(\mathrm{K})$ at different intervals (days) } \\
\cline { 2 - 5 } & 7 & 15 & 22 & 30 \\
\hline $\mathrm{T}_{1}$ & $0.89 \pm 0.01$ & $0.85 \pm 0.01$ & $0.82 \pm 0.00$ & $0.80 \pm 0.02$ \\
$\mathrm{~T}_{2}$ & $0.89 \pm 0.02$ & $0.85 \pm 0.02$ & $0.85 \pm 0.02$ & $0.79 \pm 0.02$ \\
$\mathrm{~T}_{3}$ & $0.84 \pm 0.02$ & $0.85 \pm 0.01$ & $0.83 \pm 0.01$ & $0.82 \pm 0.02$ \\
$\mathrm{~T}_{4}$ & $0.82 \pm 0.05$ & $0.82 \pm 0.05$ & $0.81 \pm 0.05$ & $0.81 \pm 0.05$ \\
\hline
\end{tabular}

Values are Mean \pm SEM of duplicate groups of 30 fish. Means in the same column with different superscripts are significantly different at $\mathrm{p}<0.05$. 
Highest condition factor was observed in treatment $\mathrm{T}_{1}(0.89 \pm 0.01)$ and lowest value was observed in $\mathrm{T}_{4}(0.81 \pm 0.05)$. Rahman et al.(6) in a study on the survival and growth of cat fish after giving selected supplemental feeds got the values of condition factor between $0.81-0.87$, which was similar with these findings.

The average daily gain was observed for mrigal fingerlings in the 30 days rearing period (Table 3). At the end of 30 days rearing period the highest ADG value was achieved by fish at $\mathrm{T}_{1}(0.03 \pm 0.00 \%)$ and the lowest value was observed at $\mathrm{T}_{4}(0.02 \pm$ $0.00 \%$ ). This result indicates that feed affect the average daily gain. Sangrattanakhul(7) found the value of ADG in Anabas testudineus ranging from 0.10 to $0.12 \mathrm{~g}$ per day, which was similar with the present findings.

Table 3 . Average daily gain (ADG) at 30 days rearing period (Mean $\pm \mathrm{SEM}$ ).

\begin{tabular}{ccccc}
\hline & \multicolumn{4}{c}{ Average daily gain at different intervals (days) } \\
\cline { 2 - 5 } Treatment & 7 & 15 & 22 & 30 \\
\hline $\mathrm{T}_{1}$ & $0.03 \pm 0.00^{\mathrm{a}}$ & $0.05 \pm 0.01^{\mathrm{a}}$ & $0.03 \pm 0.01^{\mathrm{a}}$ & $0.03 \pm 0.00^{\mathrm{a}}$ \\
$\mathrm{T}_{2}$ & $0.04 \pm 0.00^{\mathrm{a}}$ & $0.03 \pm 0.00^{\mathrm{ab}}$ & $0.02 \pm 0.00^{\mathrm{b}}$ & $0.02 \pm 0.00^{\mathrm{a}}$ \\
$\mathrm{T}_{3}$ & $0.05 \pm 0.01^{\mathrm{a}}$ & $0.04 \pm 0.00^{\mathrm{ab}}$ & $0.03 \pm 0.00^{\mathrm{ab}}$ & $0.02 \pm 0.00^{\mathrm{a}}$ \\
$\mathrm{T}_{4}$ & $0.03 \pm 0.00^{\mathrm{a}}$ & $0.03 \pm 0.00^{\mathrm{b}}$ & $0.03 \pm 0.00^{\mathrm{ab}}$ & $0.02 \pm 0.00^{\mathrm{a}}$ \\
\hline
\end{tabular}

Values are mean \pm SEM of duplicate groups of 30 fish. Means in the same column with different superscripts are significantly different at $\mathrm{p}<0.05$.

The average value of specific growth rate of mrigal fingerlings was highest in treatment $\mathrm{T}_{1}(1.65 \pm 0.29 \%)$. On the other hand, the lowest value was found at treatment $\mathrm{T}_{4}(0.56 \pm 0.11 \%)$ (Table 4$)$. The significantly highest specific growth rate in treatment $\mathrm{T}_{1}$ might be due to the fact that the fish have utilized effectively the supplied feed. Hossain and Parveen (2) recorded the highest SGR (1.80\%) of H. fossilis by supplying diet which has more or less similarities with this findings.

Table 4. Specific growth rate (SGR) at 30 days of rearing period (Mean \pm SEM).

\begin{tabular}{ccccc}
\hline \multirow{2}{*}{ Treatment } & \multicolumn{4}{c}{ Specific growth rate \% at different intervals (days) } \\
\cline { 2 - 5 } & 7 & 15 & 22 & 30 \\
\hline $\mathrm{T}_{1}$ & $1.57 \pm 0.10^{\mathrm{a}}$ & $1.65 \pm 0.29^{\mathrm{a}}$ & $1.00 \pm 0.40^{\mathrm{a}}$ & $0.79 \pm 0.16^{\mathrm{a}}$ \\
$\mathrm{T}_{2}$ & $1.21 \pm 0.12^{\mathrm{a}}$ & $0.97 \pm 0.08^{\mathrm{b}}$ & $0.60 \pm 0.09^{\mathrm{b}}$ & $0.64 \pm 0.06^{\mathrm{a}}$ \\
$\mathrm{T}_{3}$ & $1.51 \pm 0.25^{\mathrm{a}}$ & $1.05 \pm 0.09^{\mathrm{ab}}$ & $0.81 \pm 0.06^{\mathrm{ab}}$ & $0.63 \pm 0.08^{\mathrm{a}}$ \\
$\mathrm{T}_{4}$ & $1.05 \pm 0.13^{\mathrm{a}}$ & $0.88 \pm 0.05^{\mathrm{ab}}$ & $0.76 \pm 0.07^{\mathrm{ab}}$ & $0.56 \pm 0.11^{\mathrm{a}}$ \\
\hline
\end{tabular}

Values are mean \pm SEM of duplicate groups of 30 fish. Means in the same column with different superscripts are significantly different at $\mathrm{p}<0.05$. 
The feeding utilization was calculated in terms of feed conversion ratio (Table 5). The value of feed conversion ratio varied between 3.08 and 6.23. A low FCR value is an indicator of better food utilization efficiency of supplemental feed. The lowest i.e., the best FCR was observed in treatment $T_{1}$ with feed -1 and the highest i.e., the worst FCR value was recorded in treatment $\mathrm{T}_{4}$ with the feeding of feed- 4 . The observed FCR value showed significant difference between treatments. Doolgindachabaporn ${ }^{(1)}$ found FCR value of Anabas testudineus ranges between 1.8 and $3.0 \mathrm{~g}$, which has less similarities with these findings.

Table 5. Feed conversion ratio (FCR) at 30 days rearing period (Mean \pm SEM).

\begin{tabular}{lcccc}
\hline Treatment & \multicolumn{4}{c}{ Feed conversion ratio at different intervals (days) } \\
\cline { 2 - 5 } & 7 & 15 & 22 & 30 \\
\hline $\mathrm{T}_{1}$ & $3.28 \pm 0.12^{\mathrm{b}}$ & $3.48 \pm 0.16^{\mathrm{b}}$ & $3.53 \pm 0.15^{\mathrm{b}}$ & $3.08 \pm 0.10^{\mathrm{a}}$ \\
$\mathrm{T}_{2}$ & $4.12 \pm 0.11^{\mathrm{ab}}$ & $4.59 \pm 0.18^{\mathrm{a}}$ & $4.70 \pm 0.16^{\mathrm{a}}$ & $4.23 \pm 0.13^{\mathrm{a}}$ \\
$\mathrm{T}_{3}$ & $3.33 \pm 0.14^{\mathrm{b}}$ & $3.60 \pm 0.16^{\mathrm{ab}}$ & $3.72 \pm 0.18^{\mathrm{ab}}$ & $3.17 \pm 0.11^{\mathrm{a}}$ \\
$\mathrm{T}_{4}$ & $4.83 \pm 0.25^{\mathrm{a}}$ & $5.28 \pm 0.49^{\mathrm{a}}$ & $5.73 \pm 0.57^{\mathrm{ab}}$ & $6.23 \pm 0.59^{\mathrm{a}}$ \\
\hline
\end{tabular}

Values are mean \pm SEM of duplicate groups of 30 fish. Means in the same column with different superscripts are significantly different at $\mathrm{p}<0.05$.

The water quality parameters should be maintained carefully, otherwise it may be detrimental for the fish health. Poor water quality may reduce the growth rate of fish and may also make fish diseased which ultimately reduce the expected production. The value of the water quality parameters such as temperature, dissolved oxygen, light intensity, $\mathrm{pH}$ and ammonia were monitored during the experimental period.

Water temperature was found between 25.5 and $30.5^{\circ} \mathrm{C}$. The maximum temperature was recorded in $\mathrm{T}_{2}$ whereas the minimum was in $\mathrm{T}_{4}$.

Dissolved oxygen content in four treatments was 4.1 to $7.75 \mathrm{mg} / \mathrm{l}, 4.5$ to $7.25 \mathrm{mg} / \mathrm{l}, 3.8$ to $6.75 \mathrm{mg} / \mathrm{l}$ and 4.0 to $6.8 \mathrm{mg} / \mathrm{l}$, respectively. The maximum dissolved oxygen was recorded in $\mathrm{T}_{1}$ whereas the minimum was recorded in $\mathrm{T}_{3}$. The above findings have got similarities within the findings of Ali et al. ${ }^{(8)}$ observed the values of DO between 4.0 and $7.4 \mathrm{mg} / \mathrm{l}$.

Light intensity in four treatments was 126 to $562 \mathrm{~lx} / \mathrm{m}^{2}, 134$ to $660 \mathrm{~lx} / \mathrm{m}^{2}, 138$ to 615 $1 x / \mathrm{m}^{2}$ and 132 to $570 \mathrm{~lx} / \mathrm{m}^{2}$, respectively. The maximum light intensity was recorded in $\mathrm{T}_{2}$ whereas minimum temperature was recorded in $\mathrm{T}_{1}$. The variation in light intensity in different treatments might be due to different types of fish feeds used in rearing tank.

During the experimental period $\mathrm{pH}$ in four treatments were 7.99 to $8.40,7.46$ to 8.25 , 7.82 to 8.30 and 7.92 to 8.43 , respectively. The maximum $\mathrm{pH}$ was recorded in $\mathrm{T}_{4}$ whereas the minimum in $\mathrm{T}_{2}$. The above findings have similarities with that of Ali et al. ${ }^{\left({ }^{8}\right)}$ who 
observed the values of $\mathrm{pH}$ between 6.8 and 8.0. The $\mathrm{pH}$ in the system in nearly neutral zone and found no bad effect on the fish growth. Ammonia content was maximum in $\mathrm{T}_{4}$ $(0.6 \mathrm{mg} / \mathrm{l})$ while the minimum in $\mathrm{T}_{1}(0.3 \mathrm{mg} / \mathrm{l})$

The proximate composition of the experimental fish rearing in different treatments have been presented in Table 6 . Average moisture content of mrigal in treatments 1, 2, 3 and 4 were 77.2, 78.41, 76.99 and $77.86 \%$, respectively. Asadullah et al.(9) observed that moisture content in India mackerel (Rastrelliger kanagurta) varied from 70.11 to $74.41 \%$ over the period of one year. All these findings coincide well with the present results of moisture content.

Average protein content of mrigal fish in treatments 1, 2, 3 and 4 were 17.15, 15.89, 16.90 and $14.76 \%$, respectively. Nurullah et al.(3) studied the protein content of some small indigenous fish species of Bangladesh and showed that protein content was in the range of 14.08 to $21.70 \%$ with highest value in kankila and lowest in chapila. Azam et al.(10) studied protein content of different fish species and reported protein content in the range of 8.58 to $19.06 \%$.

Table 6. Proximate analysis of mrigal fingerlings after 30 days of rearing period.

\begin{tabular}{ccccc}
\hline Treatment & Moisture (\%) & Protein (\%) & Lipid (\%) & Ash (\%) \\
\hline $\mathrm{T}_{1}$ & 77.2 & 17.15 & 2.07 & 3.58 \\
$\mathrm{~T}_{2}$ & 78.41 & 15.89 & 2.22 & 3.48 \\
$\mathrm{~T}_{3}$ & 76.99 & 16.90 & 2.25 & 3.88 \\
$\mathrm{~T}_{4}$ & 77.86 & 14.76 & 2.85 & 4.53 \\
\hline
\end{tabular}

Average lipid content of mrigal fish in treatments 1, 2, 3 and 4 were 2.07, 2.22, 2.25 and $2.85 \%$, respectively. Wimalasena et al. ${ }^{(11)}$ studied on the lipid content of some commonly eaten fresh water fish and found 2.3, 4.4, 2.3 and 1.7\% lipid in stinging cat fish (H. fossilis), climbing perch (A. testudineus), tilapia (O. mossambicus) and snakehead (O. striatus), respectively.

Ash content of mrigal in four treatments were 3.58, 3.48, 3.88 and $4.53 \%$, respectively in treatments 1, 2, 3 and 4. Islam et al.(12) reported ash content of freshwater gobi (Glossogobius giuris) ranged from 0.95 to $1.52 \%$ in male and 1.06 to $1.82 \%$ in female. Mazumder et al.(13) investigated the ash content of some small indigenous fish species and recorded that mean ash content for these species ranged from 1.19 to $3.92 \%$.

From the findings of the present study it can be concluded that feed- 1 prepared with the composition of mustard oil cake, soyabean meal, rice bran, vitamin and mineral mixture can be used for better growth of mrigal fingerlings. 


\section{Acknowledgements}

Authors are grateful to the authorities of BCSIR Laboratories, Dhaka for providing laboratory facilities and also thankful to the Department of Fisheries, University of Dhaka for their assistance.

\section{References}

1. Doolgindachabaporn S 1994. Development of optimal rearing and cultural system of climbing perch, Anabas testudineus (Bloch). Doctoral Thesis, University of Manitoba, Canada. pp.189.

2. Hossain MA and S Parveen 1998. Effect of supplementary feed on the growth of singhi fish (Heteropneustes fossilis). Bangladesh J. Fish. Res. 2(2): 205-207.

3. Nurullah M, M Kamal and SH Thilsted 2003. Nutritional quality of some small indigenous fish spices of Bangladesh. pp. 151-158.

4. Marimuthu K, AC Cheen, S Muralikrishnan and D Kumar 2010. Effect of different feeding frequency on growth and survival of African catfish (Clarius gariepinus) fingerlings. Adv. Environ. Biol. 4: 187-193.

5. AOAC (Association of Official Analytical Chemists) 1995. Official Methods of Analysis. $16^{\text {th }}$ Edn. Association of official analytical chemist, Washington DC/Virginia, DC. USA.

6. Rahaman MA, N Begum and MG Hussain 1997. Effects of some selective supplemental feeds on the growth and survival of catfish (Clarias batrachus). Bangladesh J. Fish. Res. 1(2): 5558.

7. Sangrattanaksul C 1989. Effect of pelletized diets containing various levels of protein on growth and survival of climbing perch (Anabas testudineus). M.Sc. thesis. Kasetsart University. Bangkok, Thailand. pp. 74.

8. Ali MZ, MKI Haque, R Parveen, MG Hussain and MA Mazid 2005. Growth and reduction of cost of production of (Pangasius hypopthalmus) with alternate feeding schedules. Ind. J. Fish 52(4): 397-404.

9. Asadullah $\mathrm{K}$ and $\mathrm{K}$ Nisa 2011. Seasonal variation in chemical composition of the Indian mackerel (R. kanagurta) from Karachi coast. Iranian J. Fish. Sci. 10(1): 67-74.

10. Azam K, MY Ali, M Asaduzzaman, MZ Basher and NM Hossain 2004. Biochemical assessment of selected fresh fish. J. Biol. Sci. 4(1): 9-10.

11. Wimalasena $\mathrm{S}$ and MNS Jayasuriya 1996. Nutrient analysis of some fresh water fish. J. Natn. Sci. Coun. Sri Lanka. 24(1): 21-26.

12. Islam MN and MAR Joadder 2005. Seasonal variation of the proximate composition of fresh water Gobi, Glossogobius giuris (Hamilton) from the river Padma. Pak. J. Biol. Sci. 8(4): $532-536$.

13. Mazumder MSA, MM Rahman and MA Hossain. 2008. Proximate composition of some small indigenous fish species in Bangladesh. Int. J. Sustained. Crop. Prod. 3(4): 18-23. 